\title{
Nitrification and growth of autotrophic nitrifying bacteria and Thaumarchaeota in the coastal North Sea
}

\author{
B. Veuger ${ }^{1,2}$, A. Pitcher ${ }^{3}$, S. Schouten ${ }^{3,4}$, J. S. Sinninghe Damsté ${ }^{3,4}$, and J. J. Middelburg ${ }^{1,4}$ \\ ${ }^{1}$ Department of Ecosystem Studies, Netherlands Institute for Sea Research (NIOZ), Yerseke, the Netherlands \\ ${ }^{2}$ Department of Analytical and Environmental Chemistry, Vrije Universiteit Brussel (VUB), Brussel, Belgium \\ ${ }^{3}$ Department of Marine Organic Biogeochemistry, Netherlands Institute for Sea Research (NIOZ), Texel, the Netherlands \\ ${ }^{4}$ Faculty of Geosciences, Utrecht University, Utrecht, the Netherlands
}

Correspondence to: B. Veuger (bart.veuger@nioz.nl)

Received: 1 November 2012 - Published in Biogeosciences Discuss.: 28 November 2012

Revised: 25 February 2013 - Accepted: 26 February 2013 - Published: 14 March 2013

\begin{abstract}
Nitrification and the associated growth of autotrophic nitrifiers, as well as the contributions of bacteria and Thaumarchaeota to total autotrophic C-fixation by nitrifiers were investigated in the Dutch coastal North Sea from October 2007 to March 2008. Rates of nitrification were determined by incubation of water samples with ${ }^{15} \mathrm{~N}$-ammonium and growth of autotrophic nitrifiers was measured by incubation with ${ }^{13} \mathrm{C}$-DIC (dissolved inorganic carbon) in the presence and absence of nitrification inhibitors (nitrapyrin and chlorate) in combination with compoundspecific stable isotope $\left({ }^{13} \mathrm{C}\right)$ analysis of bacterial and Thaumarchaeotal lipid biomarkers. Net nitrification during the sampling period was evident from the concentration dynamics of ammonium, nitrite and nitrate. Measured nitrification rates were high $\left(41-221 \mathrm{nmol} \mathrm{NL}^{-1} \mathrm{~h}^{-1}\right)$. Ammonium assimilation was always substantially lower than nitrification - with nitrification on average contributing $89 \%$ (range 73$97 \%$ ) to total ammonium consumption.

${ }^{13} \mathrm{C}$-DIC fixation into bacterial and Thaumarchaeotal lipids was strongly reduced by the nitrification inhibitors (27-95\%). The inhibitor-sensitive ${ }^{13}$ C-PLFA (phospholipidderived fatty acid) pool was dominated by the common PLFAs 16:0, 16:1 $\omega 7 \mathrm{c}$ and 18:1 $\omega 7 \mathrm{c}$ throughout the whole sampling period and occasionally also included the polyunsaturated fatty acids 18:2 $\omega 6 \mathrm{c}$ and $18: 3 \omega 3 .{ }^{13} \mathrm{C}$-DIC fixation activity of the nitrifying bacteria was much higher than that of the nitrifying Thaumarchaeota throughout the whole sampling period, even during the peak in Thaumarchaeotal abundance and activity. This suggests that the contribution of autotrophic Thaumarchaeota to nitrification during winter in
\end{abstract}

the coastal North Sea may have been smaller than expected from their gene abundance (16S rRNA and amoA (ammonia monooxygenase)). These results emphasize the importance of direct measurements of the actual activity of bacteria and Thaumarchaeota, rather than abundance measurements only, in order to elucidate their biogeochemical importance. The ratio between rates of nitrification versus DIC fixation by bacterial nitrifiers was higher or even much higher than typical values for autotrophic nitrifiers, indicating that little DIC was fixed relative to the amount of energy that was generated by nitrification.

\section{Introduction}

Nitrification, the two-step process in which ammonium is converted to nitrate by nitrifying microbes, is an important process in the nitrogen cycle of marine waters as it links degradation of organic matter and ammonium regeneration with removal of bioavailable nitrogen through denitrification. Even though nitrification has been studied extensively, some of its pivotal aspects have remained unresolved.

One of these aspects is the coupling between nitrification (which yields energy to the nitrifying microorganisms) and growth of the nitrifiers (assimilation of $\mathrm{C}, \mathrm{N}$, etc. into new microbial biomass, which requires energy) in natural environments. Nitrifiers are generally considered to be obligate chemolithoautotrophs, which means that nitrification is their only source of energy and they can only acquire $\mathrm{C}$ through fixation of dissolved inorganic carbon (DIC). Therefore, 
nitrification rates in the field are often derived from measurements of dark fixation of ${ }^{13} \mathrm{C}$ - or ${ }^{14} \mathrm{C}$-labeled DIC in the presence and absence of nitrification inhibitors (see e.g. Brion and Billen, 1998; Andersson et al., 2006a). This approach relies on a constant ratio between $\mathrm{N}$-oxidized and $\mathrm{C}$-fixed and on tight coupling between activity and growth of nitrifiers. However, in the field, including coastal waters, these aspects have been found to be variable (e.g. Billen, 1976; Owens, 1986; Andersson et al., 2006a) and may be biased by heterotrophy amongst nitrifiers (Ward, 2008).

Another aspect of nitrification that has recently become a topic of intensive research is the identity of the microorganisms involved in nitrification. Traditionally, nitrification was thought to be performed by a relatively small group of specialized bacteria. However, in the last few years, indications have been accumulating that Thaumarchaeota (previously known as Crenarchaeota, Brochier-Armanet et al., 2008; Spang et al., 2010) may also be important players in nitrification in marine waters (Wuchter et al., 2006; Francis et al., 2007; Prosser and Nichol, 2008). This hypothesis is primarily based on: (1) The ability of Thaumarchaeota to oxidize ammonium in pure and enrichment cultures (Könneke et al., 2005; Wuchter et al., 2006; Tourna et al., 2011), (2) the presence of putative archaeal ammonia monooxygenase genes ( $a m o A$, the enzyme that catalyses ammonium oxidation) in marine waters and their dominance over bacterial $a m o A$ in various systems (Wuchter et al. 2006; Francis et al., 2005, 2007). (3) Correlations between Thaumarchaeotal biomarkers (lipids and molecular markers), archaeal amoA genes and nitrification rates (measured or inferred from DIN concentrations) in the field (e.g. Pitcher et al., 2011). However, these indications are all indirect, meaning that the actual contribution of Thaumarchaeota to nitrification in the field, including coastal waters, has so far remained largely unresolved (Nichol and Schleper, 2006; Francis et al., 2007; Prosser and Nichol, 2008; Bernhard et al., 2010; Santoro et al., 2010).

In the present study, we investigated nitrification and the associated growth of autotrophic nitrifiers in the Dutch coastal North Sea from October to March. Previous studies in the Dutch coastal North Sea revealed an annual peak in the abundance of Thaumarchaeota during winter when there was net nitrification in the water column (Wuchter et al., 2006; Pitcher et al., 2011). Combined with the much higher abundance of archaeal amoA genes than bacterial amo $A$ genes (maximum values of $4 \times 10^{5}$ copies $\mathrm{mL}^{-1}$ versus $0.2 \times 10^{5}$ copies $\mathrm{mL}^{-1}$ respectively, from Wuchter et al., 2006), this led to the hypothesis that Thaumarchaeota may be important players in nitrification in the coastal North Sea during winter.

In this study, we determined rates of nitrification by incubation of water samples with ${ }^{15} \mathrm{~N}$-ammonium, and growth of autotrophic nitrifiers was measured by incubation with ${ }^{13} \mathrm{C}$-DIC in the presence and absence of nitrification inhibitors in combination with compound-specific stable iso- tope $\left({ }^{13} \mathrm{C}\right)$ analysis of bacterial and Thaumarchaeotal lipid biomarkers. This approach allowed us to investigate the coupling between nitrification and growth of autotrophic nitrifiers as well as the relative importance of bacteria and Thaumarchaeota in total autotrophic nitrification during winter in the coastal North Sea.

\section{Materials and Methods}

\subsection{Sampling}

Water was sampled weekly from the Marsdiep channel near the island of Texel (the Netherlands) from October 2007 to March 2008. Water was sampled from the jetty in front of the Netherland Institute for Sea Research (NIOZ) with incoming tide, meaning that sampled water represents water from the coastal North Sea flowing along the Dutch coast. Water was collected from the well-oxygenated surface layer $(0-1 \mathrm{~m}$ deep) and assumed to be representative for the whole water column as water in the field is thoroughly mixed by tidal currents. Concentrations of ammonium, nitrate and nitrite and additional parameters such as temperature and salinity were measured as part of a long-term monitoring program at the NIOZ jetty. Concentrations of Thaumarchaeotal lipids and 16S rRNA, and archaeal amoA genes were measured simultaneously and are presented in Pitcher et al. (2011).

\section{$2.2 \quad{ }^{15} \mathrm{~N}$-ammonium incubations}

Every week, two glass $250 \mathrm{~mL}$ bottles were filled with $200 \mathrm{~mL}$ seawater directly after sampling. One bottle (control) was filtered directly while the other bottle received $0.1 \mu \mathrm{mol}$ ${ }^{15} \mathrm{~N}$-labeled ammonium $\left(\left(\mathrm{NH}_{4}\right)_{2} \mathrm{SO}_{4}, 98 \%{ }^{15} \mathrm{~N}\right)$, yielding a concentration of $0.5 \mu \mathrm{M}$, which corresponded to $4-20 \%$ of ambient ammonium concentrations. Labeled bottles were incubated in the dark for 1.5-4.4 h in a temperature-controlled room at in situ temperature and aerated in order to keep particulate material suspended and the water oxygenated. Water from labeled and unlabeled bottles was filtered through GF/F (glass fiber) filters ( $25 \mathrm{~mm}, 0.7 \mu \mathrm{m}$ pore size). Filtered water was frozen for analysis of concentrations and ${ }^{15} \mathrm{~N}$ content of $\mathrm{NH}_{4}^{+}$and $\mathrm{NO}_{\mathrm{x}}^{-}\left(\mathrm{NO}_{2}^{-}+\mathrm{NO}_{3}^{-}\right)$, which were used to determine nitrification rates. Filters were frozen $\left(-20^{\circ} \mathrm{C}\right)$ for analysis of total $\mathrm{N}$ and ${ }^{15} \mathrm{~N}$ content which were used to determine ${ }^{15} \mathrm{~N}$ assimilation rates. $\mathrm{NO}_{\mathrm{x}}^{-}$was extracted from water samples using an ammonia diffusion method based on Sigman et al. (1997) and Holmes et al. (1998). Briefly, $\mathrm{NH}_{4}^{+}$was first removed from the water by addition of $\mathrm{MgO}$ (converting $\mathrm{NH}_{4}^{+}$ to $\mathrm{NH}_{3}$ ) and shaking for 7 days with $\mathrm{NH}_{3}$ being trapped by a filter pack consisting of an acidified GF/D filter packed between two pieces of teflon film floating on the water. Thereafter, the filter pack was removed and Devarda's alloy was added to the water $(250 \mathrm{mg}$ per $100 \mathrm{~mL}$ water) to convert $\mathrm{NO}_{\mathrm{x}}^{-}$to $\mathrm{NH}_{4}^{+}$. A fresh filter pack was added and closed bottles were placed in an oven $\left(65^{\circ} \mathrm{C}\right)$ for 2 days and thereafter 
shaken for 6 days at room temperature. Filter packs (containing trapped ${ }^{15} \mathrm{NH}_{3}$ derived from ${ }^{15} \mathrm{NO}_{\mathrm{x}}^{-}$) were rinsed with $10 \% \mathrm{HCl}$ and demineralized water, dried, and stored in a desiccator until analysis. Concentrations and ${ }^{15} \mathrm{~N}$-enrichment of the filters from the filter packs, as well as the filters with SPM (suspended particulate matter) from the incubations, were analyzed on an elemental analyzer coupled to an isotope ratio mass spectrometer (EA-IRMS (elemental analyzer-isotopic ratio mass spectrometer), Thermo Delta V).

\subsection{C-DIC incubations}

Along with sampling for the ${ }^{15} \mathrm{~N}$ incubations, water was collected approximately every second week for incubation with ${ }^{13} \mathrm{C}$-DIC in order to measure DIC-fixation rates. Per sampling, four containers $(40 \mathrm{~L})$ were filled with $20 \mathrm{~L}$ of field water. Containers were placed in a temperature-controlled room at in situ temperature and water was aerated to keep particulate material in suspension and the water oxygenated. One of the containers received $5 \mathrm{mg} \mathrm{L}^{-1}$ of nitrapyrin, an inhibitor of ammonium oxidation also known as N-Serve (Brion and Billen, 1998; de Bie et al., 2002), and one received $10 \mathrm{mM}$ of sodium chlorate, an inhibitor of nitrite oxidation (Belser and Mays, 1980). All four containers were left to settle in darkness for about $2 \mathrm{~h}$. Thereafter, $4 \mathrm{mmol}{ }^{13} \mathrm{C}$-bicarbonate $\left(\mathrm{NaH}_{2} \mathrm{CO}_{3}, 99 \%{ }^{13} \mathrm{C}\right)$ was added to the two containers with and one without inhibitors, resulting in a concentration of $200 \mu \mathrm{M}$, which corresponded to $\pm 10 \%$ of ambient DIC concentrations. One container did not receive ${ }^{13} \mathrm{C}$-DIC and was used as a control to determine the ambient ${ }^{13} \mathrm{C}$ background. Labeled containers were incubated for about $24 \mathrm{~h}$ in darkness. Thereafter, $100 \mathrm{~mL}$ of water from the containers was filtered through a GF/F filter $(25 \mathrm{~mm}$ id, $0.7 \mu \mathrm{m}$ pore size $)$ for analysis of ${ }^{13} \mathrm{C}$ in total SPM, $1 \mathrm{~L}$ was filtered through another $\mathrm{GF} / \mathrm{F}$ filter ( $47 \mathrm{~mm}$ id, $0.7 \mu \mathrm{m}$ pore size) for analysis of concentrations of and ${ }^{13} \mathrm{C}$ in phospholipid-derived fatty acids (PLFAs), and the remaining $\sim 19 \mathrm{~L}$ were filtered through another $\mathrm{GF} / \mathrm{F}$ filter $(0.7 \mu \mathrm{m}$ pore size $)$ for analysis of concentrations of and ${ }^{13} \mathrm{C}$ in intact polar lipid derived-glycerol dibiphytanyl glycerol tetraethers (IPL-GDGTs), which includes the Thaumarchaeotal biomarker crenarchaeol (see Pitcher et al., 2011). Filters were stored frozen $\left(-20^{\circ} \mathrm{C}\right)$. Small filters for analysis of bulk SPM were freeze-dried and analyzed by EA-IRMS (Thermo Delta V) for concentrations and ${ }^{13} \mathrm{C}$-enrichment of organic carbon (OC).

PLFAs were extracted from frozen filters in chloroformmethanol-water using a modified Bligh and Dyer method as presented in detail in Boschker (2004). Briefly, the total extract was fractionated on silica gel into different classes by polarity, with the most polar fraction containing the PLFAs. PLFAs were derivatized by mild methanolysis yielding fatty acid methyl esters (FAMEs) that were analyzed for concentrations and ${ }^{13} \mathrm{C}$-enrichment by gas chromatography-combustion-isotope ratio mass spectrometry (GC-c-IRMS) on a Hewlett-Packard 6890 GC with a
Thermo type III combustion interface and Thermo Delta Plus IRMS. A selection of samples was also analyzed by regular gas chromatography-mass spectrometry (GC-MS) to verify

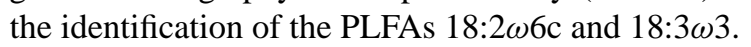

IPL-GDGTs, including those containing crenarchaeol as a core lipid, were extracted and analyzed as presented in Pitcher et al. (2011). Briefly, IPL-GDGTs were extracted in $\mathrm{MeOH}: \mathrm{DCM}$ : phosphate buffer using a modified Bligh and Dyer technique, isolated using silica gel chromatography followed by acid hydrolysis to release the core lipid GDGTs. Concentrations of the latter, as a proxy for IPLGDGTs, were analyzed using high performance liquid chromatography (HPLC) - atmospheric pressure chemical ionization (APCI) - mass spectrometry (MS). ${ }^{13} \mathrm{C}$-enrichment of GDGT-derived biphytanes was analyzed by GC-c-IRMS after treatment with $\mathrm{HI} / \mathrm{LiAlH}_{4}$ to release the biphytanes.

\subsection{Calculations}

Stable isotope results will be presented as $\Delta \delta$ values and as concentrations excess ${ }^{13} \mathrm{C}$ or ${ }^{15} \mathrm{~N} . \Delta \delta X$ was calculated as $\delta X_{\text {sample }}-\delta X_{\text {control }}$ with $X$ being ${ }^{13} \mathrm{C}$ or ${ }^{15} \mathrm{~N}$. $\delta X$ was calculated as $\delta X(\% o)=\left[\left(R_{\text {sample }} / R_{\text {standard }}-1\right] \times 1000\right.$. For ${ }^{15} \mathrm{~N}, \quad R={ }^{15} \mathrm{~N} /{ }^{14} \mathrm{~N}$ and $R_{\text {standard }}=0.003677$. For ${ }^{13} \mathrm{C}$, $R={ }^{13} \mathrm{C} /{ }^{12} \mathrm{C} \quad$ and $\quad R_{\text {standard }}=0.011180$. Concentrations of excess ${ }^{15} \mathrm{~N}$ or ${ }^{13} \mathrm{C}$ were calculated: concentration $X=\left[\left(\right.\right.$ at $\% X_{\text {sample }}-$ at $\left.\left.\% X_{\text {control }}\right) / 100\right] \times[$ concentration $\mathrm{N}$ or $\mathrm{C}$ in sample] with $X$ representing ${ }^{15} \mathrm{~N}$ or ${ }^{13} \mathrm{C}$. Unlabeled samples were used as control to correct for ambient ${ }^{13} \mathrm{C}$ and ${ }^{15} \mathrm{~N}$. At $\% X$ was calculated from $\delta X$ : at $\% X=\left[100 \times R_{\text {standard }} \times\left(\delta X_{\text {sample }} / 1000\right)+1\right] /\left[1+R_{\text {standard }}\right.$ $\left.\times\left(\delta X_{\text {sample }} / 1000\right)+1\right]$.

Nitrification rates were calculated as (concentration excess $\left.{ }^{15} \mathrm{~N}_{\text {in }} \mathrm{NO}_{\mathrm{x}}^{-}\right) \times\left(\right.$total $\mathrm{NH}_{4}^{+} /$added $\left.{ }^{15} \mathrm{NH}_{4}^{+}\right) /($incubation time (h)), with total $\mathrm{NH}_{4}^{+}=$ambient $\mathrm{NH}_{4}^{+}+$added ${ }^{15} \mathrm{NH}_{4}^{+}$. No correction was made for isotope dilution of the ${ }^{15} \mathrm{NH}_{4}^{+}$pool due to potential production of ${ }^{14} \mathrm{NH}_{4}^{+}$during the incubations because comparison of measured at $\%{ }^{15} \mathrm{~N}_{\text {for }} \mathrm{NH}_{4}^{+}$at the end of the incubations with that at the start of the incubations (calculated) showed that dilution was negligible. Ammonium assimilation rates were calculated as (concentration excess ${ }^{15} \mathrm{~N}$ in $\left.\mathrm{SPM}\right) \times\left(\right.$ total $\mathrm{NH}_{4}^{+}$/added $\left.{ }^{15} \mathrm{NH}_{4}^{+}\right) /($incubation time (h)). DIC-fixation rates were calculated as (concentration excess ${ }^{13} \mathrm{C}$ in $\left.X\right) \times($ total DIC/added DIC)/(incubation time (h)), with $X=$ bulk SPM, PLFA or crenarchaeol and total DIC $=$ ambient DIC + added DIC.

\section{Results and Discussion}

\subsection{DIN concentration dynamics}

The observed dissolved inorganic nitrogen (DIN) concentration dynamics are consistent with the general pattern in DIN concentrations in previous winters at the same sampling 
location (Wuchter et al., 2006; Pitcher et al., 2011), indicating that we studied a representative winter season. The occurrence of nitrification in the coastal North Sea during the sampling period was directly evident from the concentration dynamics of ammonium, nitrate and nitrite that showed distinctly different trends over time (Fig. 1). Ammonium concentrations had highest values in November/December $(\sim 10 \mu \mathrm{M})$ and decreased during the rest of the sampling period. Nitrate concentrations showed the opposite trend with lowest values in October and a gradual increase up to highest values in February $(\sim 80 \mu \mathrm{M})$. Nitrite concentrations peaked in December/January $(\sim 2 \mu \mathrm{M})$ and decreased rapidly thereafter. The decrease in ammonium concentrations and the concurrent increase in nitrate concentrations indicates net nitrification during the winter season. The accumulation of nitrite up to mid-January suggests that rates of ammonium oxidation were higher than rates of nitrite oxidation during this period while the opposite occurred in February/March. Moreover, given that accumulation of nitrite was minor compared to that of nitrate, it seems that rates of both processes were similar and tightly coupled during the whole winter season and hence that the temporary accumulation of nitrite resulted from only subtle differences in rates for the two processes. However, it should be noted here that these concentration changes are governed not only by production and consumption processes within the water column, but also by import and export from adjacent water bodies and exchange with the underlying sediments.

\subsection{Nitrification rates}

Measured nitrification rates in the ${ }^{15} \mathrm{NH}_{4}^{+}$incubations ranged from 41 to $221 \mathrm{nmol} \mathrm{NL}^{-1} \mathrm{~h}^{-1}$ with a rather erratic pattern over time, including peaks in November and February (Fig. 2, Table 1). These rates are within the range of rates reported for different coastal waters (40-3000 $\mathrm{nmol} \mathrm{N} \mathrm{L}^{-1} \mathrm{~h}^{-1}$ ) (overview in de Bie et al., 2002). Nitrification may have been stimulated by the continuous aeration of the bottles, which was necessary to prevent settling of the particulate material and possible associated reduction of oxygen concentrations. The correctness of the measured (gross) nitrification rates is supported by comparison with the rates required to explain the increase in nitrate concentrations between October and February (Fig. 1). The latter required a nitrification rate of $23 \mathrm{nmol} \mathrm{NL^{-1 }} \mathrm{h}^{-1}$, which compares reasonably well with measured (gross) ${ }^{15} \mathrm{~N}$-rates taking into account that part of the formed nitrate must have been removed by sedimentary uptake and/or denitrification (i.e. the increase in nitrate concentrations reflects the net nitrification rate). The potential stimulation by aeration is unlikely to have affected the main results regarding the coupling between nitrification and DIC fixation as this stimulation would have occurred in both the ${ }^{15} \mathrm{NH}_{4}^{+}$and ${ }^{13} \mathrm{C}$-DIC incubations. Moreover, aeration may have affected the competition between Thaumarchaeota and bacteria in case of differential sensitiv-

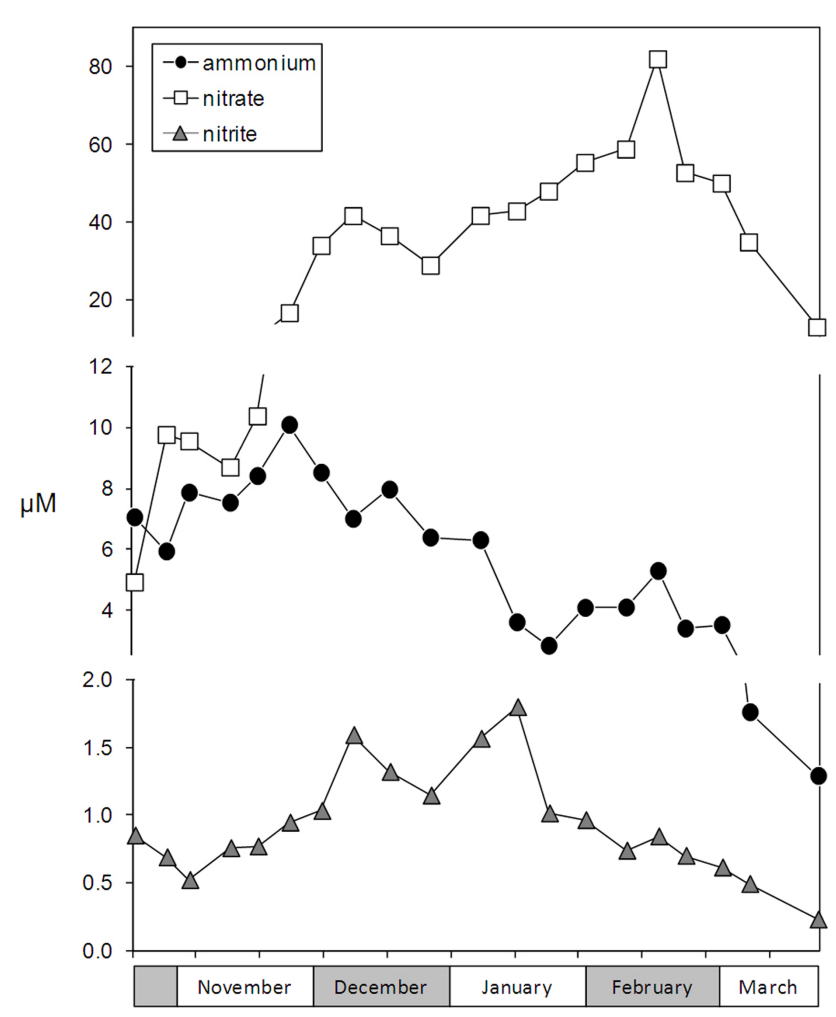

Fig. 1. Concentrations of ammonium, nitrate and nitrite during the winter of 2007-2008 in the Marsdiep channel. Note breaks in y-axis.

ity towards stirring and/or oxygen concentrations. However, the turbulent, oxygenated conditions in the incubation bottles were actually representative of conditions in the water column at the sampling location where winds, waves, and tidal currents cause thorough mixing and full aeration of the water column. Therefore, we feel that conditions in the incubation bottles were at least reasonably representative for the field situation, and certainly more representative than incubations without any mixing.

\subsection{Fate of ammonium: nitrification versus assimilation}

The two main processes consuming ammonium in oxic coastal waters are nitrification and assimilation. However, the relative importance of nitrification versus assimilation in the total consumption of ammonium has received relatively little attention. Lipschultz et al. (1986) measured rates of nitrification (ammonium oxidation and nitrite oxidation) and ammonium uptake in the Delaware River and found both processes to be of similar importance. Ward (2005) measured both nitrification and ammonium uptake along a depth profile in Monterey Bay and found assimilation to be the dominant sink for ammonium in the surface layers $(<25 \mathrm{~m})$ whereas rates for both processes were in the same range for deeper layers. Clark et al. (2011) reported assimilation rates that 
Table 1. Rates of nitrification and DIC fixation with corresponding $\mathrm{N}_{\mathrm{OX}} / \mathrm{C}_{\mathrm{fix}}$ ratios. See text for details.

\begin{tabular}{|c|c|c|c|c|c|c|c|c|c|}
\hline & 23 Oct & 13 Nov & $10 \mathrm{Dec}$ & $27 \mathrm{Dec}$ & 15 Jan & $30 \mathrm{Jan}$ & $15 \mathrm{Feb}$ & 6 Mar & $21 \mathrm{Mar}$ \\
\hline \multicolumn{10}{|l|}{ Nitrification } \\
\hline$\left(\mathrm{nmol} \mathrm{NL} \mathrm{L}^{-1} \mathrm{~h}^{-1}\right)$ & & 221 & 62 & 89 & 89 & 43 & 91 & 87 & 69 \\
\hline \multicolumn{10}{|c|}{ PLFA-based estimate of DIC fixation by bacterial nitrifiers } \\
\hline$\left(\mathrm{nmol} \mathrm{CL} \mathrm{L}^{-1} \mathrm{~h}^{-1}\right)$ & 0.9 & 0.3 & 0.4 & 1.2 & 1.1 & 1.5 & 1.7 & 0.8 & 0.2 \\
\hline $\mathrm{N}_{\mathrm{OX}} / \mathrm{C}_{\mathrm{fix}}$ & & 686 & 172 & 75 & 81 & 28 & 54 & 103 & 286 \\
\hline \multicolumn{10}{|c|}{ Measured DIC fixation in bulk SPM } \\
\hline$\left(\mathrm{nmol} \mathrm{CL} \mathrm{L}^{-1} \mathrm{~h}^{-1}\right)$ & 8.1 & 1.7 & 1.4 & 1.9 & 2.1 & 2.4 & 2.0 & 3.0 & 14.2 \\
\hline $\mathrm{N}_{\mathrm{ox}} / \mathrm{C}_{\mathrm{fix}}$ & & 129 & 44 & 46 & 42 & 18 & 45 & 29 & 5 \\
\hline
\end{tabular}

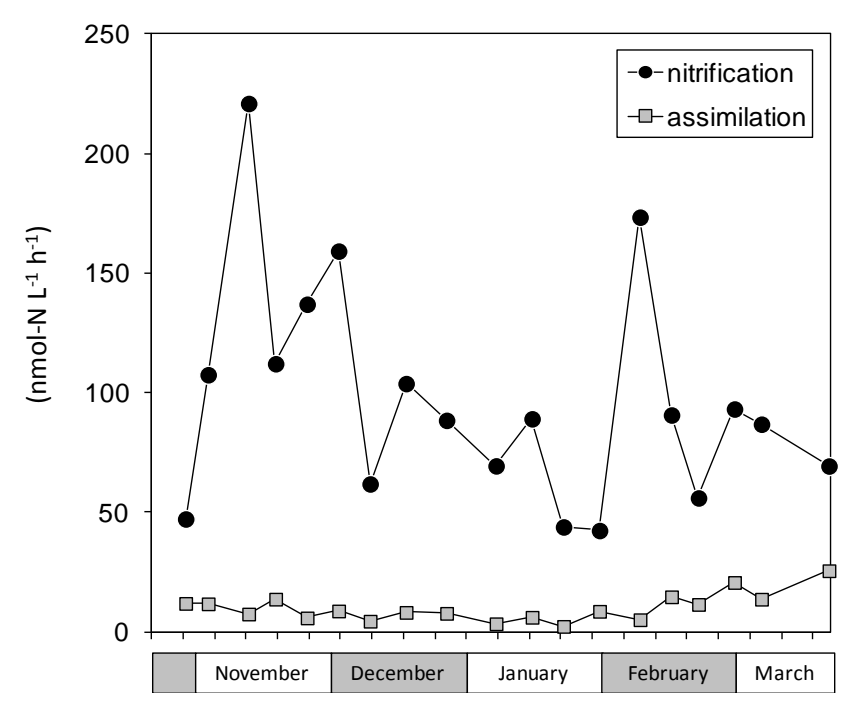

Fig. 2. Rates of nitrification and ammonium assimilation in incubations with ${ }^{15} \mathrm{~N}$-ammonium.

were 2-50 times higer than ammonium oxidation rates in surface waters in the northeast Atlantic. Assimilation and nitrification were also found to be important processes for consumption of ammonium throughout the year in the Scheldt Estuary (Andersson et al., 2006a, b; Brion et al., 2008).

For the present study, ammonium assimilation rates were 2-26 nmol $\mathrm{NL}^{-1} \mathrm{~h}^{-1}$ with lowest values in January/February and a subsequent increase to highest values on 18 March (Fig. 2), which is the time of the year when the first algal bloom takes place. On average, nitrification and assimilation contributed $89 \%$ (range 73-97\%) and $11 \%$ (range 3-27\%), respectively, to total ammonium consumption. Hence, nitrification was the primary sink for ammonium during winter in the coastal North Sea. The highest contribution of assimilation (27\%) for the last sampling (21 March) indicates that assimilation will be more important during spring when the phytoplankton spring bloom causes enhanced assimilation of ammonium by algae and associated bacteria. In general, our results indicate that both nitrification and assimilation are important processes with respect to the fate of ammonium in coastal waters.

\subsection{Activity of autotrophic nitrifying bacteria}

Analysis of fixation of ${ }^{13} \mathrm{C}$ - or ${ }^{14} \mathrm{C}$-labeled DIC in the presence and absence of a nitrification inhibitor is a common method to measure growth of a nitrifying microbial community in the field (see e.g., de Bie et al., 2002 and references therein). In the present study, this method is combined with compound-specific stable isotope analysis of PLFAs to investigate DIC-fixation by nitrifying bacteria.

Bacterial ${ }^{13} \mathrm{C}$-fixation resulted in clear ${ }^{13} \mathrm{C}$-enrichment of the PLFAs with corresponding $\Delta \delta^{13} \mathrm{C}$ values for individual PLFAs mostly between $10 \%$ and $100 \%$ and a maximum of $1250 \%$. The nitrification inhibitors strongly reduced ${ }^{13} \mathrm{C}$-fixation into PLFAs (Fig. 3 and Table 2). On average, ${ }^{13} \mathrm{C}$-fixation into summed PLFAs was inhibited by $77 \%$ (range 41-95\%) and $70 \%$ (range 27-92\%) by nitrapyrin and chlorate respectively (Table 2 ). The degree of inhibition by both inhibitors correlated well over the sampling period, except for the last sampling when inhibition by chlorate was relatively low (Fig. 3).See Sect. 3.5 for further discussion of these results. The composition of the PLFA pool of the active nitrifying bacteria is represented by the relative composition of the ${ }^{13} \mathrm{C}$-labeled PLFA pool that was inhibited by nitrapyrin (Fig. 4). Inhibition by nitrapyrin is used here because it was somewhat higher than inhibition by chlorate and because nitrapyrin inhibits the rate limiting step in nitrification (ammonium oxidation). However, the use of values inhibited by nitrapyrin versus chlorate makes little difference for the resulting estimates and the corresponding discussion below.

The ${ }^{13} \mathrm{C}$-labeled PLFA pool that was inhibited by the nitrification inhibitors was dominated by a small set of PLFAs, with the common PLFAs 16:0, 16:1 $\omega 7 \mathrm{c}$ and 18:1 $\omega 7 \mathrm{c}$ being abundant throughout the whole sampling period and mostly dominating the inhibited ${ }^{13} \mathrm{C}$-labeled PLFA pool (Fig. 4). The ${ }^{13} \mathrm{C}$-labeled PLFA profile is similar to the profile from a comparable experiment in the Scheldt Estuary (de Bie et

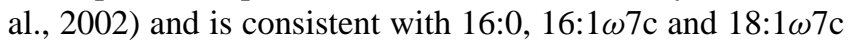


Table 2. Inhibition of ${ }^{13} \mathrm{C}$-DIC fixation in PLFAs and crenarchaeol by nitrapyrin and chlorate. Inhibition $(\%)$ was calculated as: $\left(\left(\left({ }^{13} \mathrm{C}\right.\right.\right.$ fixation without inhibitor $)-\left({ }^{13} \mathrm{C}\right.$ fixation with inhibitor $\left.)\right) /\left({ }^{13} \mathrm{C}\right.$ fixation without inhibitor $\left.)\right) \times 100$. Missing values correspond to concentrations and/or ${ }^{13} \mathrm{C}$ enrichment below limit of detection.

\begin{tabular}{lrrrrrrrrr}
\hline Nitrapyrin & 23 Oct & 13 Nov & 10 Dec & 27 Dec & 15 Jan & 30 Jan & 15 Feb & 6 Mar & 21 Mar \\
\hline $16: 0$ & 44 & 36 & 83 & 90 & 98 & 92 & 96 & 95 & 86 \\
$16: 1 \omega 7 \mathrm{c}$ & 55 & 40 & 72 & 66 & 79 & 71 & 74 & 77 & 85 \\
$18: 1 \omega 7 \mathrm{c}$ & 49 & 51 & 61 & 49 & 78 & 70 & & 74 & 78 \\
$18: 2 \omega 6 \mathrm{c}$ & 23 & 100 & & 100 & & & 99 & & \\
$18: 3 \omega 3$ & & 81 & & 100 & & 100 & 100 & & \\
\hline summed PLFAs & 45 & 41 & 75 & 88 & 92 & 88 & 95 & 87 & 84 \\
\hline crenarchaeol & & & 72 & & 68 & 88 & 89 & & \\
\hline
\end{tabular}

\begin{tabular}{lrrrrrrrrr}
\hline Chlorate & 23 Oct & 13 Nov & 10 Dec & 27 Dec & 15 Jan & 30 Jan & 15 Feb & 6 Mar & 21 Mar \\
\hline $16: 0$ & & 43 & 62 & 80 & 94 & 94 & 90 & 97 & 10 \\
$16: 1 \omega 7 \mathrm{c}$ & & 5 & 41 & 55 & 55 & 54 & 64 & 83 & 21 \\
$18: 1 \omega 7 \mathrm{c}$ & & 42 & 51 & 50 & 70 & 60 & 49 & 80 & 44 \\
$18: 2 \omega 6 \mathrm{c}$ & 100 & 100 & & 91 & & & 100 & & \\
$18: 3 \omega 3$ & 100 & 81 & & 100 & & 100 & 100 & & 27 \\
\hline summed PLFAs & 100 & 44 & 53 & 82 & 85 & 86 & 90 & 92 & \\
\hline crenarchaeol & & 33 & & & 68 & 69 & & \\
\hline
\end{tabular}

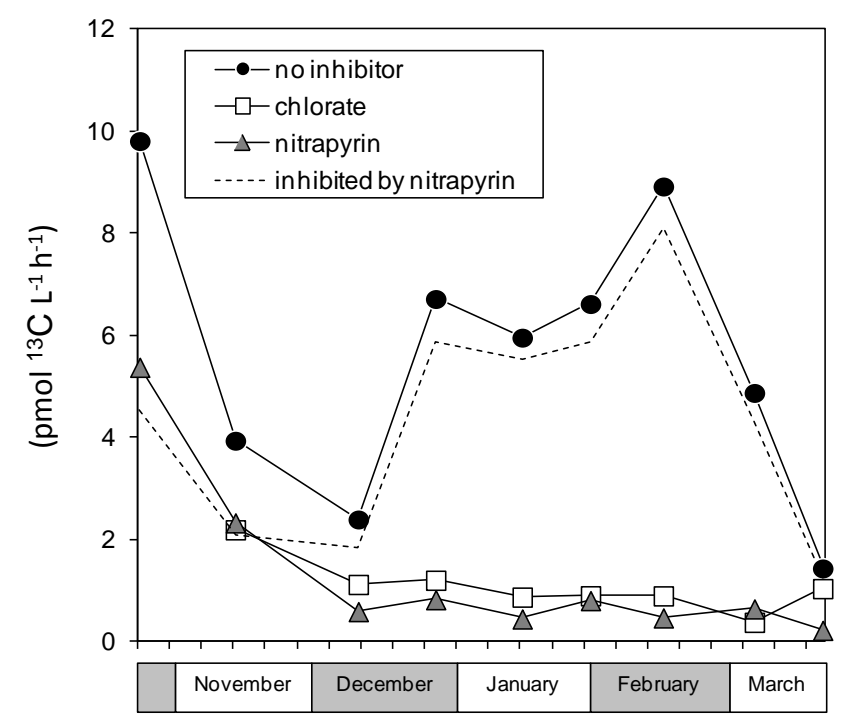

Fig. 3. Rates for ${ }^{13} \mathrm{C}$-incorporation into summed PLFAs in incubations with nitrapyrin, chlorate, and without inhibitors. Dashed line indicates ${ }^{13} \mathrm{C}$-fixation inhibited by nitrapyrin (difference between no inhibitor and nitrapyrin).

being the dominant PLFAs in nitrifying bacteria (Blumer et al., 1969; Lipski et al., 2001).

In addition to the three common PLFAs, the inhibited ${ }^{13}$ C-labeled PLFA pool occasionally also comprised a substantial contribution by the polyunsaturated fatty acids (PU-

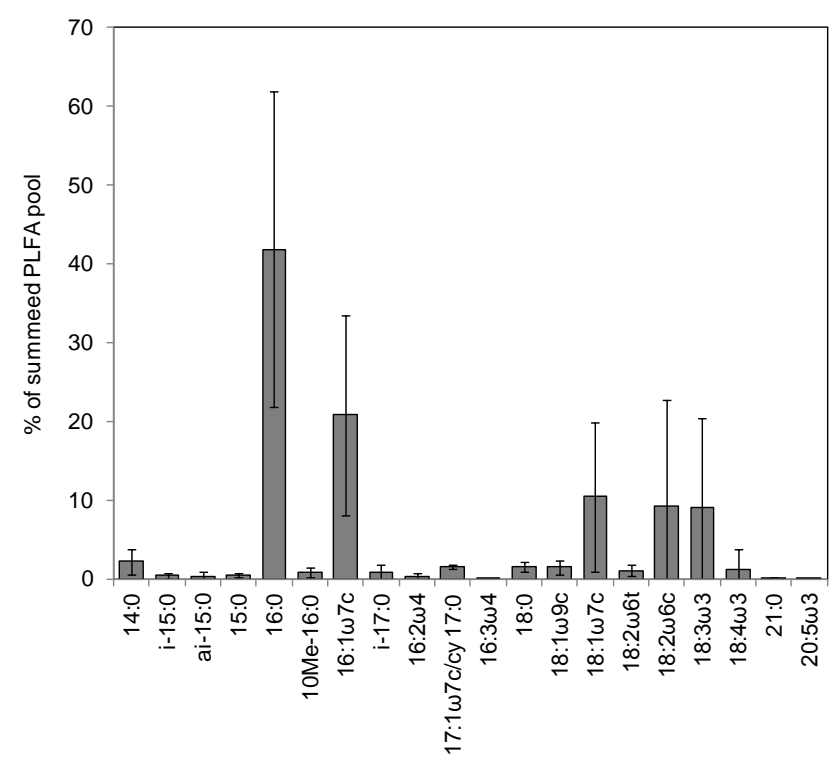

Fig. 4. Relative contributions (\%) of individual PLFAs to ${ }^{13} \mathrm{C}$-fixation in total PLFAs inhibited by nitrapyrin. Values are averages for the whole sampling period, error bars indicate corresponding standard deviations.

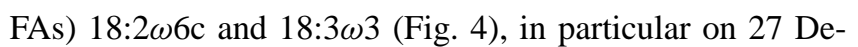
cember and 15 February. These two PUFAs showed high ${ }^{13} \mathrm{C}$-enrichment with $\Delta \delta^{13} \mathrm{C}$ values up to an order of mag-

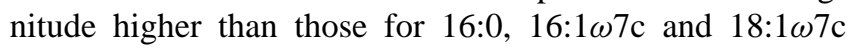



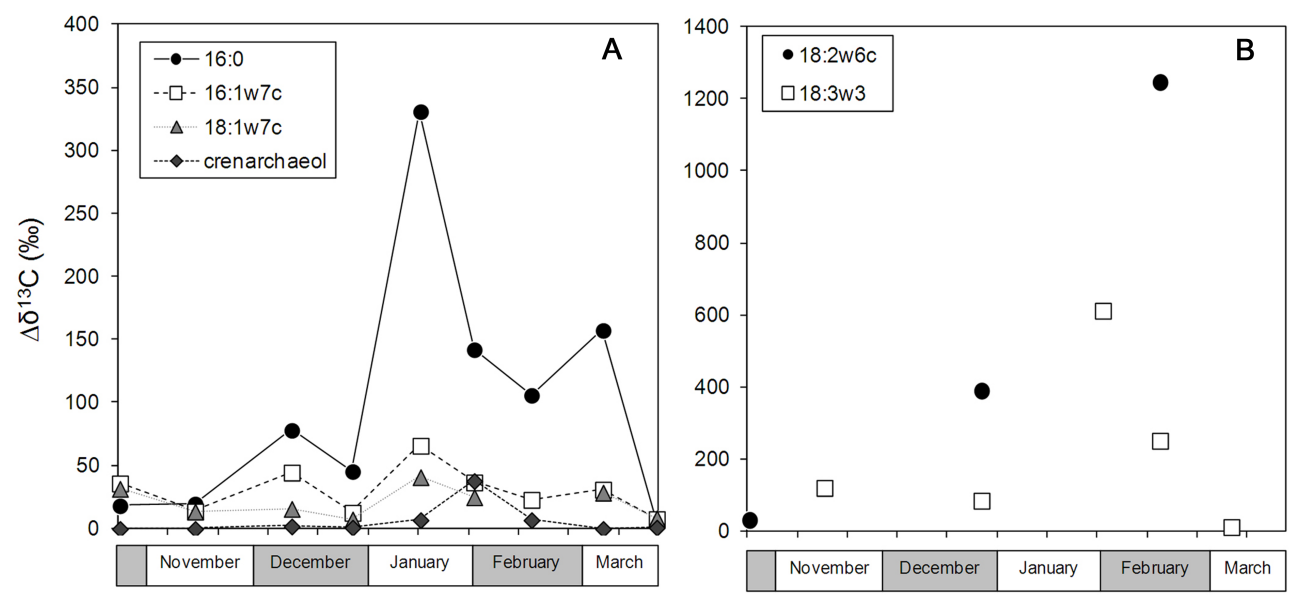

Fig. 5. $\Delta \delta^{13} \mathrm{C}$ values for individual PLFAs and crenarchaeol inhibited by nitrapyrin (i.e. $\left(\Delta \delta^{13} \mathrm{C}\right.$ without inhibitor) $-\left(\Delta \delta^{13} \mathrm{C}\right.$ with nitrapyrin)). Note difference in scales for $(\mathbf{A})$ and $(\mathbf{B})$.

(Fig. 5). However, their concentrations were low and in some samples below the limit of detection, which resulted in a highly variable contribution of these two PUFAs to the total ${ }^{13}$ C-labeled PLFA pool (Fig. 4). The presence of these PUFAs in the ${ }^{13} \mathrm{C}$-labeled PLFA pool is intriguing since PUFAs are generally considered to be a specific feature of eukaryotes. However, the measured ${ }^{13} \mathrm{C}$-fixation into the PUFAs in the present study is unlikely to reflect ${ }^{13} \mathrm{C}$-fixation by eukaryotes (phytoplankton) because of low algal activity during winter and because incubations were performed in darkness (i.e. no light for photosynthesis). Moreover, ${ }^{13} \mathrm{C}$-fixation into these PUFAs was clearly inhibited by the nitrification inhibitors (Table 2) which suggests that these PUFAs may have been present in nitrifying bacteria. PUFAs have been reported to be present in some marine bacteria (DeLong and Yayanos, 1986; Russell and Nichols, 1999) and have been suggested to be an adaptation to low temperatures (Russell and Nichols, 1999), which is consistent with the production of PUFAs during winter in the present study.

\subsection{Contributions of bacteria and Thaumarchaeota to total autotrophic C-fixation by nitrifiers}

The ${ }^{13} \mathrm{C}$-tracer approach in combination with ${ }^{13} \mathrm{C}$ analysis of bacterial and Thaumarchaeotal lipid biomarkers offers the unique opportunity to quantify the relative contributions of bacteria and Thaumarchaeota to total DIC-fixation by the nitrifying microbial community.

A first clue on the involvement of both groups in nitrification in the present study is provided by the clear inhibitory effect of the nitrification inhibitors on ${ }^{13} \mathrm{C}$-fixation by bacteria (PLFAs, Fig. 3, Table 2) as well as Thaumarchaeota (crenarchaeol, Table 2), meaning that a substantial fraction of ${ }^{13} \mathrm{C}$-fixation by both groups was indeed directly linked to nitrification. The inhibition of growth of archaeal nitrifiers by chlorate and nitrapyrin has so far only been reported by Park et al. (2010). Interestingly, the activity of both groups was inhibited by nitrapyrin (inhibiting ammonium oxidation) as well as by chlorate (inhibiting nitrite oxidation) and the degree of inhibition was very similar for both inhibitors (Fig. 3, Table 2). For bacteria, this is consistent with nitrifying bacteria comprising both ammonium oxidizers and nitrite oxidizers. For Thaumarchaeota, the strong inhibition by chlorate is unexpected as Thaumarchaeota are generally considered to be ammonium oxidizers only. One potential explanation may be that Thaumarchaeota were, directly or indirectly, involved in nitrite oxidation. Another explanation for the strong inhibition by chlorate may be direct inhibition of ammonium oxidation by chlorite produced from the reduction of chlorate by nitrite oxidizers (Hynes and Knowles, 1983). Moreover, we cannot exclude the possibility that non-nitrifying autotrophs were also inhibited by chlorate.

A more quantitative comparison of ${ }^{13} \mathrm{C}$-fixation by nitrifying bacteria versus Thaumarchaeota is provided by comparison of $\Delta \delta{ }^{13} \mathrm{C}$ values for PLFAs (representing bacteria) versus crenarchaeol from the intact polar lipid (IPL) GDGT pool (representing Thaumarchaeota) (Fig. 5). $\Delta \delta^{13} \mathrm{C}$ values inhibited by nitrapyrin for the PLFAs 16:0,16:1 $\omega 7 \mathrm{c}$ and $18: 1 \omega 7 \mathrm{c}$ ranged from 8 to $331 \%$ (seasonal averages of $101 \pm 102 \%$, $30 \pm 18 \%$, and $22 \pm 12 \%$ o respectively) whereas values for the two PUFAs were occasionally even much higher (Fig. 4). In contrast, $\Delta \delta^{13} \mathrm{C}$ values inhibited by nitrapyrin for crenarchaeol were mostly very low $(<2 \%$ o) except for 15 and 30 January and 15 February when $\Delta \delta^{13} \mathrm{C}$ values were $7 \%$, $38 \%$, and $7 \%$ respectively (Fig. 5). Only on 30 January, during the short peak in Thaumarchaeotal biomass (Pitcher et al., 2011), total Thaumarchaeotal ${ }^{13} \mathrm{C}$-fixation (without inhibitors) reached a similar level $\left(\Delta \delta^{13} \mathrm{C}=38 \%\right.$ ) as that of the nitrifying bacteria $\left(\Delta \delta^{13} \mathrm{C}=25-142 \%\right.$ ). This comparison between lipid markers for both groups may contain some bias from the relatively low degradability of Thaumarchaeotal lipids compared to that of bacterial PLFA's (Harvey et al., 
1986; Logemann et al., 2011), which may have resulted in a relatively large background pool of "dead" Thaumarchaeotal lipids that effectively diluted the $\Delta \delta^{13} \mathrm{C}$ values. Nevertheless, these results at least provide an indication that ${ }^{13} \mathrm{C}$-fixation activity of the nitrifying bacteria was much higher than that of the nitrifying Thaumarchaeota throughout the whole sampling period.

For full quantification of the contributions of bacteria and Thaumarchaeota to total DIC fixation by nitrifiers, ${ }^{13} \mathrm{C}$-fixation in the specific compounds was converted to total DIC-fixation by bacterial and Thaumarchaeotal nitrifiers. This comparison is not biased by the above mentioned possible differences in background pools of "dead" lipid markers for both groups resulting from possible differences in degradability as it only deals with the ${ }^{13} \mathrm{C}$-labeled (i.e., freshly produced) material. For bacteria, inhibited ${ }^{13} \mathrm{C}$-fixation in summed PLFAs (dashed line in Fig. 3) was converted to total bacterial ${ }^{13} \mathrm{C}$-fixation assuming a bacterial PLFA content of $6 \%$ (Brinch-Iversen and King, 1990) and converted to total DIC fixation taking into account the $10 \%{ }^{13} \mathrm{C}$ enrichment of the total DIC pool in the incubations (i.e., $\times 10$ ). Resulting total bacterial DIC-fixation rates range from 0.2 to $1.7 \mathrm{nmol} \mathrm{C} \mathrm{L}^{-1} \mathrm{~h}^{-1}$ (average $=0.90$ ) (Table 1). For the Thaumarchaeota, $\mathrm{C}$ fixed in crenarchaeol was converted to total Thaumarchaeotal lipids assuming that crenarchaeol made up $31 \%$ of total lipids (Pitcher et al., 2011) and C fixed in total lipids was then converted to that in total Thaumarchaeotal biomass using a conversion factor of $\times 13$ (from Lipp et al., 2008). For 30 January, the sampling occasion with highest concentrations of and ${ }^{13} \mathrm{C}$-fixation in crenarchaeol, this yielded an estimated rate of total DIC-fixation by Thaumarchaeota of $0.02 \mathrm{nmol} \mathrm{CL}^{-1} \mathrm{~h}^{-1}$. For comparison, the estimated DIC-fixation rates for nitrifying bacteria for this particular sampling was $1.5 \mathrm{nmol} \mathrm{CL^{-1 }} \mathrm{h}^{-1}$ (Table 1). This two orders of magnitude difference indicates that DIC fixation by nitrifying Thaumarchaeota was much lower than that by nitrifying bacteria, even at the peak of Thaumarchaeotal abundance and activity. Assuming a similar stoichiometry between nitrification and DIC-fixation for both autotrophic nitrifiers, these results suggest that the contribution of autotrophic Thaumarchaeota to nitrification during winter in the coastal North Sea was negligible. A methodological point to take into account here is that water was filtered over GF/F filters with a pore size of $0.7 \mu \mathrm{m}$ while individual cells of bacteria and archaea can be smaller than $0.7 \mu \mathrm{m}$ and therefore may not all have been retained on the filters. However, we do not expect this to be a major issue for turbid coastal waters, such as in the present study, where a large fraction of the microbial community is typically associated with larger particles and where rapid clogging of the filter reduces the effective pore size. This is supported by results from Herfort et al. (2007) who analysed GDGT concentrations in the North Sea with sequential filters of $0.7 \mu \mathrm{m}$ and $0.2 \mu \mathrm{m}$ pore size and only recovered $<5 \%$ on the $0.2 \mu \mathrm{m}$ filters, and by results from Pitcher et al. (2011) who found good correla- tion between AOA (ammonia-oxidizing archaea) DNA concentrations trapped on $0.2 \mu \mathrm{m}$ filters with crenarchaeol concentrations trapped on $0.7 \mu \mathrm{m}$ filters. Moreover, since both archaeal and bacterial cells can be smaller than $0.7 \mu \mathrm{m}$, we do not expect a strong bias in our results concerning DIC assimilation by bacteria versus Thaumarchaeota.

The ${ }^{13} \mathrm{C}$-DIC fixation results are consistent with the observed absence of a correlation between Thaumarchaeotal abundance (crenarchaeol concentrations) and nitrification rates. Given that nitrification in the coastal North Sea primarily takes place in winter, this suggests that the overall importance of autotrophic Thaumarchaeota for nitrification in these waters is relatively low.

Results from the present study appear to contradict the findings of Wuchter et al. (2006) who found low bacterial amoA copy numbers compared to those for archaeal amoA at the same sampling site in the winter of 2002-2003. Assuming that general trends for both winters are comparable, which is supported by the consistent seasonal trends (Pitcher et al., 2011), this indicates that amoA copy numbers alone do not necessarily provide a good indication of the actual nitrification activity. The apparent small contribution of Thaumarchaeota to total autotrophic nitrification in the coastal North Sea in the present study is consistent with recent findings for various coastal systems that also indicate a minor contribution of AOA to total nitrification (Mosier and Francis, 2008; Bernhard et al., 2010; Wankel et al., 2011). A potentially important controlling factor here is the relatively high concentration of ammonium and organic matter in coastal systems because Thaumarchaeota are thought to have competitive advantage in low ammonium systems due to their ability to exploit low ammonium concentrations (MartensHabbena et al., 2009; Pester et al., 2011). Similar observations have recently been made for soils where AOB appear to dominate under high ammonia concentrations (e.g. Di et al., 2010; Verhamme et al., 2011). For open ocean systems, various recent studies also report the absence of a correlation between AOA abundance and nitrification rates (Santoro et al., 2010; Newell et al., 2011) and a small contribution of Thaumarchaeota to total microbial autotrophy (Varela et al., 2011). On balance, results from the present study illustrate that still very little is known about the actual functions and importance of Thaumarchaeota in marine $\mathrm{N}$-cycling and emphasize the importance of direct measurements of the actual activity of bacteria and Thaumarchaeota in order to elucidate their biogeochemical importance.

\subsection{Nitrification rates versus growth of autotrophic nitrifiers}

In order to investigate the coupling between $\mathrm{N}$-oxidation and $\mathrm{C}$-fixation, the ratio between $\mathrm{N}$-oxidation $\left(\mathrm{N}_{\mathrm{Ox}}\right)$ and $\mathrm{C}$ fixation $\left(\mathrm{C}_{\mathrm{fix}}\right)$ was calculated for estimated bacterial DIC fixation (as already addressed in the previous section) and for measured total dark DIC fixation in bulk SPM (Table 1). 
Thaumarchaeota were not taken into account here since microbial DIC fixation was dominated by bacteria (see previous section). Results for ${ }^{13} \mathrm{C}$-fixation into bulk SPM concern the treatment without inhibitors because the ${ }^{13} \mathrm{C}$ enrichment of SPM for incubations with inhibitors was below the limit of detection. The average $\mathrm{N}_{\mathrm{ox}} / \mathrm{C}_{\text {fix }}$ ratio for bacterial DIC fixation was 186 (range $=28-686$ ) and the average $\mathrm{N}_{\mathrm{ox}} / \mathrm{C}_{\text {fix }}$ ratio for total DIC fixation was 45 (range $=5-129$ ) (Table 1). Out of these values, the PLFA-based ratios contain some uncertainty from the conversion of ${ }^{13} \mathrm{C}$-fixation into PLFAs to total bacterial ${ }^{13} \mathrm{C}$ fixation. However, the good agreement between PLFA-based estimates of DIC-fixation and measured total DIC-fixation (Table 1) indicates that these estimates were at least in the right order of magnitude. Contrarily, $\mathrm{N}_{\mathrm{ox}} / \mathrm{C}_{\mathrm{fix}}$ ratios based on measured bulk DIC-fixation may be underestimates as these may include DIC-fixation by non-nitrifying organisms (i.e., those that were not affected by nitrification inhibitors). Hence, $\mathrm{N}_{\mathrm{ox}} / \mathrm{C}_{\mathrm{fix}}$ ratios for the total nitrifying community must have been in between those derived from PLFAs and those from total DIC-fixation.

Regardless of which values are most accurate, the $\mathrm{N}_{\mathrm{ox}} / \mathrm{C}_{\text {fix }}$ ratios in Table 1, except those for 21 March, are almost all higher, and in some cases much higher, than typical ratios of 6-19 reported for (enrichment) cultures of nitrifying bacteria (Billen, 1976; Helder and de Vries, 1983; Belser, 1984; Owens, 1986) and 2-30 for nitrifiers in natural waters (Feliatra and Bianchi, 1993; Bianchi et al., 1997; Andersson et al., 2006a). In comparison to these values, some of the $\mathrm{N}_{\mathrm{ox}} / \mathrm{C}_{\mathrm{fix}}$ ratios in the present study are very high, suggesting that relatively little DIC was fixed compared to the amount of energy generated by nitrification. This may be due to a high energy requirement for growth of the autotrophic nitrifiers under field conditions, which were not as optimal as those in cultures. One of these suboptimal conditions may have been low temperature, given that the present study was performed during winter (water temperatures of $4-11^{\circ} \mathrm{C}$ ). However, this is an unlikely explanation because $\mathrm{N}_{\mathrm{ox}} / \mathrm{C}_{\text {fix }}$ ratios were actually lowest in the middle of winter when temperatures were lowest and were relatively high at the start and end of the sampling period when temperatures were highest (i.e, opposite to expected, based on negative effect of temperature).

Another possible explanation for the high $\mathrm{N}_{\mathrm{ox}} / \mathrm{C}_{\mathrm{fix}}$ ratios is acquisition of carbon by the nitrifiers via mixotrophic or heterotrophic pathways (i.e., using organic material as Csource instead of fixing DIC). Various nitrifying bacteria, in particular nitrite oxidizers, have been shown to be able to use organic carbon, or a mixture of organic and inorganic carbon, as a carbon source for growth (Ward, 2008). The nitrifying bacteria Nitrosomonas and Nitrobacter have been shown to assimilate carbon from organic substrates (Wallace et al., 1970) and to be capable of full heterotrophic growth (Hall 1982 and references therein). Next to bacterial nitrifiers, Thaumarchaeotal nitrifiers may also have obtained their carbon from organic sources (i.e., mixotrophy or heterotrophy). Marine (Thaum) archaeota have been shown to be able to take up amino acids (Ouverney and Fuhrman, 2000; Teira et al., 2006; Varela et al., 2008) and urea (Alonso-Sáez et al., 2012) and results from recent studies indicate that nitrifying (Thaum) archaeota are not as strictly chemoautotrophic as they were previously assumed to be (Mußman et al., 2011; Pester et al., 2011; Tourna et al., 2011). Heterotrophic carbon acquisition by nitrifiers may be a particularly relevant phenomenon in coastal waters such as the coastal North Sea as these are relatively rich in suspended and dissolved organic matter.

A related phenomenon that may also be relevant for the present study is so-called heterotrophic nitrification. This concerns a form of nitrification in which ammonium or organic $\mathrm{N}$ is converted to nitrite and nitrate by heterotrophic microorganisms without an apparent energy gain (Jetten et al., 1997; Jetten, 2001; Ward, 2008). Heterotrophic nitrification can be coupled to denitrification in a single bacterium (e.g., Castignetti, 1990) but its exact mechanisms and functions are not clear. Heterotrophic nitrification has primarily been studied in soils, while very little is known about its potential importance in marine systems (see Ward, 2008). In the present study, heterotrophic nitrification may have accounted for part of total nitrification when ${ }^{15} \mathrm{~N}$-labeled ammonium was used as a substrate and when the resulting nitrite or nitrate was not immediately denitrified. Under these conditions, heterotrophic nitrification provides an alternative or complementary explanation for the high $\mathrm{N}_{\mathrm{ox}} / \mathrm{C}_{\text {fix }}$ ratios as it may have contributed to total nitrification $\left({ }^{15} \mathrm{~N}\right.$-rates $)$ but not to ${ }^{13} \mathrm{C}$-DIC fixation.

Acknowledgements. We thank Marco Houtekamer and Peter van Breugel of the analytical lab of NIOZ-Yerseke for stable isotope analysis of filters and PLFAs, Pieter van Rijswijk for PLFA extractions. Kathie Siedenberg is thanked for stable isotope analysis of crenarchaeol. Katja Philippart and colleagues are thanked for nutrient analysis. This work was funded by the Darwin Center for Biogeosciences (project 142.16.1052) by grants to JSSD and JJM. BV was also supported by an Odysseus grant (G.0929.08) awarded to F. Meysman by the Flemish Fund for Scientific Research (FWO).

Edited by: C. Robinson

\section{References}

Alonso-Sáez, L., Waller, A. S., Mende, D. R., Bakker, K., Farnelid, H., Yager, P. L., Lovejoy, C., Tremblay, J. E., Potvin, M., Heinrich, F., Estrada, M., Riemann, L., Bork, P., Pedrós-Alió, C., and Bertilsson, S.: Role for urea in nitrification by polar marine Archaea, Proc. Natl. Acad. Sci. USA, 109, 17989-17994, doi:10.1073/pnas.1201914109, 2012.

Andersson, M. G. I., Brion, N., and Middelburg J. J.: Comparison of nitrifier activity versus growth in the Scheldt estuary - a turbid, tidal estuary in northern Europe, Aquat. Microb. Ecol., 42, 149158, 2006a.

Andersson M. G. I., van Rijswijk, P., and Middelburg, J. J.: Uptake of dissolved inorganic nitrogen, urea and amino acids in the 
Scheldt estuary: comparison of organic carbon and nitrogen uptake, Aquat. Microb. Ecol., 44, 303-315, 2006b.

Belser L. W.: Bicarbonate uptake by nitrifiers: effects of growth rate, $\mathrm{pH}$, substrate concentration, and metabolic inhibitors, Appl. Environ. Microbiol. 48, 1100-1104, 1984.

Belser, L. W. and Mays, E. L.: Specific inhibition of nitrite oxidation by chlorate and its use in assessing nitrification in soils and sediments, Appl. Environ. Microbiol., 39, 505-510, 1980.

Bernhard, A. E., Landry, Z. C., Blevins A., de la Torre, J. R., Giblin A. E., and Stahl, D. A.: Abundance of ammonia-oxidizing Archaea and Bacteria along an estuarine salinity gradient in relation to potential nitrification rates, Appl. Environ. Microbiol., 76, 1285-1289, doi:10.1128/AEM.02018-09, 2010.

Bianchi, M., Feliatra,F., Tréguer, P., Vincendeau, M., and Morvan, J.: Nitrification rates, ammonium and nitrate distribution in upper layers of the water column and in sediments of the Indian sector of the Southern Ocean, Deep Sea Res. II, 44, 1017-1032, 1997.

de Bie, M. J. M., Starink, M., Boschker, H. T. S., Peene J. J., and Laanbroek, H. J.: Nitrification in the Schelde estuary: methodological aspects and factors influencing its activity, FEMS Microbiol. Ecol., 42, 99-107, 2002.

Billen, G.: Evaluation of nitrifying activity in sediments by dark 14C-bicarbonate incorporation, Water Res., 10, 51-57, doi:10.1016/0043-1354(76)90157-3, 1976.

Blumer, M., Chase, T., and Watson, S. W.: Fatty acids in the lipids of marine and terrestrial nitrifying bacteria, J. Bacteriol., 99, 366370, 1969.

Boschker, H. T. S.: Linking microbial community structure and functioning: stable isotope $\left({ }^{13} \mathrm{C}\right)$ labeling in combination with PLFA analysis, 1673-1688, in: Molecular Microbial Ecology Manual II: Kowalchuk, G. A., de Bruijn, F. J., Head, I. M., Akkermans A. D., and van Elsas, J. D., Kluwer Academic Publishers, 2004.

Brinch-Iversen, J. and King, G.M.: Effects of substrate concentration, growth rate, and oxygen availability on relationships among bacterial carbon, nitrogen and phospholipid phosphorus content, FEMS Microbiol. Ecol., 74, 345-356, 1990.

Brion, N. and Billen, G.: A reassessment of the H14CO3- incorporation method for measuring autotrophic nitrification and its use to estimate the biomass of nitrifying bacteria, Rev. Sci. Eau, 11, 283-302, 1998.

Brion, N., Andersson, M. G. I., Elskens, M., Diaconu, C., Baeyens, W., Dehairs, F., and Middelburg, J. J.: Nitrogen cycling, retention and export in a eutrophic temperate macrotidal estuary, Mar. Ecol.-Prog. Ser., 357, 87-99, doi:10.3354/meps07249, 2008.

Brochier-Armanet, C., Boussau, B., Gribaldo, S., and Forterre, P.: Mesophilic crenarchaeota: proposal for a third archaeal phylum, the Thaumarchaeota, Nat. Rev. Microbiol., 6, 245-252, doi:10.1038/nrmicro1852, 2008.

Castignetti, D.: Bioenergetic examination of the heterotrophic nitrifier-denitrifier Thiosphaera pantotropha, edited by: van Leeuw, A., J. Microbiol., 58, 283-289, 1990.

Clark, D. R., Miller, P. I., Malcolm, E., Woodward, S., and Rees, A. P.: Inorganic nitrogen assimilation and regeneration in the coastal upwelling region of the Iberian Peninsula, Limnol. Oceanogr., 56, 1689-1702, http://www.aslo.org/lo/toc/vol_56/issue_5/1689. html, 2011.

DeLong, E. F. and Yayanos, A. A.: Biochemical function and ecological significance of novel bacterial lipids in deep-sea procary- otes, Appl. Environ. Microb. 51, 730-737, 1986.

Di, H. J., Cameron, K. C., Shen, J., Winefield, C. S., O'Callaghan, M., Bowatte, S., and He, J.: Ammonia-oxidizing bacteria and archaea grow under contrasting soil nitrogen conditions, FEMS Microbiol. Ecol., 72, 386-394, doi::10.1111/j.15746941.2010.00861.x, 2010.

Feliatra, F. and Bianchi, M.: Rates of nitrification and carbon uptake in the Rhône river plume (northwestern mediterranean sea), Microb. Ecol., 26, 21-28, 1993.

Francis, C. A., Roberts, K. J., Beman, J. M., Santoro, A. E., and Oakley, B. B.: Ubiquity and diversity of ammoniaoxidizing archaea in water columns and sediments of the ocean, Proc. Natl. Acad. Sci. USA, 102, 14683-14688, doi:10.1073/pnas.0506625102, 2005.

Francis, C. A., Beman, J. M., and Kuypers, M. M. M.: New processes and players in the nitrogen cycle: the microbial ecology of anaerobic and archaeal ammonia oxidation, ISME J., 19-27, doi:10.1038/ismej.2007.8, 2007.

Hall, G. H.: Apparent and measured rates of nitrification in the hypolimnion of a mesotrophic lake. Appl. Environ. Microb. 43, 542-547, 1982.

Harvey, H. R., Fallon, R. D., and Patton, J. S.: The effect of organic matter and oxygen on the degradation of bacterial membrane lipids in marine sediments, Geochim. Cosmochim. Ac., 50, 795-804, 1986.

Helder, W. and de Vries, R. T. P.: Estuarine nitrite maxima and nitrifying bacteria (Ems-Dollard estuary), Neth. J. Sea Res., 17, 1-18, 1983.

Herfort, L., Schouten, S., Abbas, B., Veldhuis, M. J. W., Coolen, M. J. L., Wuchter, C., Boon, J. P., Herndl, G. J., Sinninghe Damsté, J. S.: Variations in spatial and temporal distribution of Archaea in the NorthSea in relation to environmental variables, FEMS. Microbiol. Ecol., 62, 242-257, 2007.

Holmes, R. M., McClelland, J. W., Sigman, D. M., Fry, B., and Peterson, B. J.: Measuring N-15-NH4+ in marine, estuarine and fresh waters: An adaptation of the ammonia diffusion method for samples with low ammonium concentrations, Mar. Chem., 60, 235-243, 1998.

Hynes, R. K. and Knowles, R.: Inhibition of chemoautotrophic nitrification by sodium chlorate and sodium chlorite: a reexamination, Appl. Environ. Microb., 45, 1178-1182, 1983.

Jetten, M. S. M.: New pathways for ammonia conversion in soil and aquatic systems, Plant Soil, 230, 9-19, 2001.

Jetten, M. S. M., Logemann, S., Muyzer, G., Robertson, L. A., de Vries, S., van Loosdrecht, M. C. M., and Kuenen, J. G.: Novel principles in the microbial conversion of nitrogen compounds, edited by: van Leeuw A., J. Microbiol., 71, 75-93, 1997.

Könneke, M., Bernhard, A. E., de la Torre, J. R., Walker, C. B., Waterbury, J. B., and Stahl, D. A.: Isolation of an autotrophic ammonia-oxidizing marine archaeon, Nature, 437, 543-546, doi:10.1038/nature03911, 2005.

Lipp, J. S., Morono, Y., Inagaki, F., and Hinrichs, K.: Significant contribution of Archaea to extant biomass in marine subsurface sediments, Nature, 454, 991-994. doi:10.1038/nature07174, 2008.

Lipschultz, F., Wofsy, S. C., and Fox, L. E.: Nitrogen metabolism of the eutrophic Delaware River ecosystem, Limnol. Oceanogr., 31, 701-716, 1986. 
Lipski, A., Spieck, E., Makolla, A., and Altendorf, K.: Fatty acid profiles of nitrite-oxidizing bacteria reflect their phylogenetic heterogeneity. System, Appl. Microbiol. 24, 377-384, 2001.

Logemann, J., Graue, J., Köster, J., Engelen, B., Rullkötter, J., and Cypionka, H.: A laboratory experiment of intact polar lipid degradation in sandy sediments, Biogeosciences, 8, 2547-2560, doi:10.5194/bg-8-2547-2011, 2011.

Martens-Habbena, W., Berube, P. M., Urakawa, H., de la Torre, J. R., and Stahl, D. A.: Ammonia oxidation kinetics determine niche separation of nitrifying Archaea and Bacteria, Nature, 461, 976-979, 2009.

Mosier A. C. and Francis, C. A.: Relative abundance and diversity of ammonia-oxidizing archaea and bacteria in the San Francisco Bay estuary, Environ. Microbiol., 10, 3002-3016, doi:10.1111/j.1462-2920.2008.01764.x, 2008.

Mußmann, M., Britob, I., Pitcher, A., Sinninghe Damsté, J. S., Hatzenpichler, R., Richter, A., Nielsen, J. L., Nielsen, P. H., Müller, A., Daims, H., Wagner, M., and Head, I. M.: Thaumarchaeotes abundant in refinery nitrifying sludges express amoA but are not obligate autotrophic ammonia oxidizers, Proc. Natl. Acad. Sci. USA, 108, 16771-16776, doi:10.1073/pnas.1106427108, 2011.

Newell, S. E., Babbin, A. R., Jayakumar, A., and Ward, B. B.: Ammonia oxidation rates and nitrification in the Arabian Sea, Global Biogeochem. Cy., 25, GB4016, doi:10.1029/2010GB003940, 2011.

Nicol, G. W. and Schleper, C.: Ammonia-oxidising Crenarchaeota: important players in the nitrogen cycle?, Trends Microbiol., 14, 207-212, 2006.

Ouverney, C. C. and Fuhrman, J. A.: Marine planktonic archaea take up amino acids, Appl. Environ. Microb. 66, 4829-4833, 2000.

Owens, N. J. P. : Estuarine nitrification: a naturally occurring fluidized bed reaction?, Estuar. Coast. Shelf Sci., 22, 31-44, 1986.

Park, B., Park, S., Yoon, D., Schouten, S., Sinninghe Damste J. S., and Rhee, S.: Cultivation of autotrophic ammoniaoxidizing archaea from marine sediments in coculture with sulfur-oxidizing bacteria, Appl. Environ. Microb. 76, 75757587, doi:10.1128/AEM.01478-10, 2010.

Pester, M., Schleper, C., and Wagner, M.: The Thaumarchaeota: an emerging view of their phylogeny and ecophysiology, Curr. Opin. Microbiol., 14, 300-306, 2011.

Pitcher, A., Siedenberg, K., Wuchter, C., Schouten, S., and Sinninghe Damsté, J. S.: Crenarchaeol tracks winter blooms of ammonia-oxidizing Thaumarchaeota in the coastal North Sea, Limnol. Oceanogr., 56, 2308-2318, doi:10.4319/lo.2011.56.6.2308, 2011.

Prosser, J. I. and Nicol, G. W.: Relative contributions of archaea and bacteria to aerobic ammonia oxidation in the environment, Environ. Microbiol., 10, 2931-2941, doi:10.1111/j.14622920.2008.01775.x, 2008.

Russell, N. J. and Nichols, D. S.: Polyunsaturated fatty acids in marine bacteria - a dogma rewritten, Microbiology, 145, 767-779, 1999.

Santoro, A. E., Casciotti, K. L., and Francis, C. A.: Activity, abundance and diversity of nitrifying archaea and bacteria in the central California Current, Environ. Microbiol., 12, 1989-2006, doi:10.1111/j.1462-2920.2010.02205.x, 2010.
Sigman, D. M., Altabet, M. A., Michener, R., McCorkle, D. C., Fry, B., and Holmes, R. M.: Natural abundance-level measurement of the nitrogen isotopic composition of oceanic nitrate: an adaptation of the ammonia diffusion method, Mar. Chem., 57, 227-242, 1997.

Spang, A., Hatzenpichler, R., Brochier-Armanet, C., Rattei, T., Tischler, P., Spieck, E., Streit, W., Stahl, D. A., Wagner, M., and Schleper, C.: Distinct gene set in two different lineages of ammonia-oxidizing archaea supports the phylum Thaumarchaeota, Trends Microbiol., 18, 331-340, 2010.

Teira, E., van Aken, H., Veth, C., and Herndl, G. J.: Archaeal uptake of enantiomeric amino acids in the meso- and bathypelagic waters of the North Atlantic, Limnol. Oceanogr., 51, 60-69, 2006.

Tourna, M., Stieglmeier, M., Spang, A., Könneke.,M., Schintlmeister, A., Urich, T., Engeld, M., Schloter, M., Wagner, M., Richter, A., and Schleper, C.: Nitrososphaera viennensis, an ammonia oxidizing archaeon from soil, Proc. Natl. Acad. Sci. USA, 108, 8420-8425, doi:10.1073/pnas.1013488108, 2001.

Varela, M. M., van Aken, H. M., Sintes, E., and Herndl, G. J.: Latitudinal trends of Crenarchaeota and Bacteria in the meso- and bathypelagic water masses of the Eastern North Atlantic, Environ. Microbiol., 10, 110-124, doi:10.1111/j.14622920.2007.01437.x, 2008.

Varela, M. M., van Aken, H. M., Sintes, E., Reinthaler, T., and Herndl, G. J.: Contribution of Crenarchaeota and Bacteria to autotrophy in the North Atlantic interior, Environ. Microbiol., 13, 1524-1533, doi:10.1111/j.1462-2920.2011.02457.x, 2011.

Verhamme, D. T., Prosser, J. I., and Nicol, G. W.: Ammonia concentration determines differential growth of ammonia-oxidising archaea and bacteria in soil microcosms, ISME J., 5, 1067-1071, 2011.

Wallace, W., Knowles, S. E., and Nicholas, D. J. D.: Intermediary metabolism of carbon compounds by nitrifying bacteria, Arch. Mikrobiol., 70, 26-42, 1970.

Wankel, S. D., Mosier, A. C., Hansel, C. M., Paytan, A., and Francis, C. A.: Spatial variability in nitri?cation rates and ammoniaoxidizing microbial communities in the agriculturally impacted Elkhorn Slough estuary, California, Appl. Environ. Microbiol., 77, 269-280, 2011.

Ward, B. B.: Temporal variability in nitrification rates and related biogeochemical factors in Monterey Bay, USA, Mar. Ecol.-Prog. Ser., 292, 97-109, 2005.

Ward, B. B.: Nitrification in Marine Systems, in: "Nitrogen in the Marine Environment", edited by: Capone, D. G., Bronk, D. A., Mulholland M. R., and Carpenter, E. J., Academic Press (2008), 199-261, doi:10.1016/B978-0-12-372522-6.00005-0, 2008.

Wuchter, C., Abbas, B., Coolen, M. J. L., Herfort, L., van Bleijswijk, J., Timmers, P., Strous, M., Teira, E., Herndl, G. J., Middelburg, J. J., Schouten, S., and Sinninghe Damsté, J. S.: Archaeal nitrification in the ocean, Proc. Natl. Acad. Sci. USA, 103, 12317-12322, doi:10.1073/pnas.0600756103, 2006. 